\title{
Understanding the motivation of associate teachers in early childhood education
}

\author{
Debbie Woolston
}

\begin{abstract}
Practicum is understood as a critical part of initial teacher education, and associate teachers play a vital and influential role for student teachers in their practicum experience. A substantial amount of research has focused on understanding the perspective of student teachers during their practicums, as well as the requirements of the associate teacher role. However, there is little information regarding the motivation of associate teachers in undertaking this type of a role. This article draws on the findings of a study that considered associate teachers as members of communities of practice and looked at what informed their understandings around their motivation for becoming and remaining associate teachers.
\end{abstract}

\section{Introduction}

$D$

racticum placements are a requirement of all stages of initial teacher education programmes, and the role of associate teachers is vital to their success (Ferrier-Kerr, n.d.; Jaipal, 2009; Roland \& Beckford, 2010; Sanders, 2005; Whatman \& MacDonald, 2017). In particular, Beck and Kosnik (2000) view associate teachers as "key contributors to pre-service teacher education" (p. 207). Associate teachers are directly involved in students' learning and development, and typically fulfil key responsibilities such as providing supervision, discussing best practices, role-modelling, and showing expertise when it comes to relating theory to practice in a meaningful and constructive manner (McDonald, 2003; Sanders, Dowson, \& Sinclair, 2005). Sanders (2005) notes that associate teachers are typically adept at discussing practice, connecting practice to theory, and encouraging students to think more deeply.

The main purpose of the associate teacher role, in the context of the practicum experience, is to foster professional relationships and collaborative partnerships between students and themselves, and with other teachers, tamariki, and whānau (Education Council, 2017; Graves, 2010; Haigh, Pinder, \& McDonald 2006). To be specific, Turnbull (2005) stated that "the ability to establish appropriate professional relationships [is] fundamental to teaching and essential to student teachers' success during practicum" (p. 204). In carrying out this role, the views, background experience, and teaching practices of associate teachers directly influence the personal and professional development of student teachers (Haigh et al., 2006; Jaipal, 2009). This is because numerous professional discussions and observations take place during practicums, where important ideas are shared by the associate teacher, collectively reflected upon, and often incorporated into the students' teaching practice (Ferrier-Kerr, 2009; Kim \& Danforth, 2012; McDonald, 2009; Moody, 2009). For instance, Le Cornu (2010) stated that associate teachers were found to provide "encouraging and challenging scaffolding for the process of learning to teach" (p. 200).

Given the importance of practicums as a part of initial teacher education, a number of studies (Beck \& Kosnik, 2000; McDonald, 2003; Moles et al., 2012) have looked at the experiences of the student and the tasks and responsibilities of the associate teacher, but not at what motivates them to take on and carry out the associate teacher role. This is problematic because associate teachers play a key role in the practicum process, and to 
disregard or fail to understand their motivation poses a risk of isolating them and creating an environment that makes them reluctant to continue in the position long term. Landt (2004), Simpson, Hastings, and Hill (2007), and Sinclair, Dowson, and Thistleton-Martin (2006) have analysed the benefits of being an associate teacher, but not whether these benefits motivate them to undertake or remain in the role. For instance, Simpson et al. (2007) investigated the benefits for associate teachers working with student teachers in rural communities in Australia—both early childhood and primary schools. They classified three main groupings of benefit: personal, which included outcomes, reflection, and growth; professional, which included reflection, management, and leadership; and, lastly, technical, which encompassed strategies, skills, and resources. Based on this, it was determined that "existing professional experience programmes provide excellent opportunities for collaborative inquiry and hence professional development" (p. 496). Similarly, Russell and Russell's (2011) inquiry found that working with student teachers "enhanced and 'recharged' their teaching skills and promoted self-reflection" (n.p.) for some associate teachers. Landt's (2004) investigation also identified that working with student teachers improved associate teachers' practice regarding reflection, observation, experimentation, and collaboration. Finally, Ganser (2002) found that teachers were motivated to take up the associate teacher role because it provided them, and their centre, with an opportunity to be part of a wider learning community. Specifically, most of the participants noted that, as associate teachers, they were able to expand their knowledge and leadership skills in new ways, and apply what they learnt to their work environment, which made the experience "often powerful, both personally and professionally” (p. 380).

Overall, there is much literature looking at the benefits of being an associate teacher, but most of it is dated and does not explicitly deal with associate teacher motivation. To address this, the study underpinning this article investigated why teachers are motivated to become, and remain, associate teachers. This is useful, in that recognising and listening to what motivates associate teachers enables an understanding of measures to keep them in the role. Also, it gives an idea of how changes could be implemented in initial teacher education (ITE) to ensure that teachers are motivated to take up and remain in associate teacher positions.

\section{Methodology}

A social constructivist theoretical framework guided the research process, and data were collected by using a qualitative inquiry approach. This provided a way to contextualise the accounts of participants and their experiences holistically, in light of their relationships, family, and community (Burr, 2015). The focus was on the personal experiences of associate teachers and the factors that motivate them. Ethical approval was granted by the Faculty of Education Research Ethics Committee of the University of Waikato. The study was undertaken in a provincial city in New Zealand. Nine associate teachers (Table 1) were recruited on the basis that they were eager to be involved and had between them a range of experience as associate teachers (first time associate teacher, less than 2 years, 2 to 3 years, over 3 years). Data were categorised by examining each individual interview around the following questions that pertained to motivation: What were your reasons for becoming an associate teacher? What motivates you to continue working in the associate teacher role? What do you feel is the most satisfying aspect of being an associate teacher? What do you feel is the least satisfying aspect of the role?

\section{Findings}

(a) What motivates teachers to become associate teachers?

The primary motivation for early childhood teachers to become associate teachers is that they want to support student teachers, help others, and give something back to the profession. For instance, Hebe was clear that she thought "it is partly our responsibility to oncoming teachers as a profession to support one another and do that sort of role". This was further supported by both Hera, "I feel responsible that I need to be supporting students who are taking an interest and want to be part of this journey in the early childhood career field", and Leto, who stated "I want to give a little back, like people supported me through my journey to become a teacher, so to support others in the same way".

A secondary motivation was that student teachers helped associate teachers to remain up to date with what was happening in tertiary study, teacher registration, and early childhood practice. To be specific, Demeter was clear in stating "I did it to keep myself up to date and practising good practice and knowing about teacher criteria and practice". This was also shown by Rhea who said, "I did this to keep me current as to what was going on in the early childhood field". Some

TABLE 1. DEMOGRAPHIC INFORMATION ABOUT PARTICIPANTS

\begin{tabular}{|c|c|c|c|c|}
\hline $\begin{array}{l}\text { Participant name }{ }^{*} \text { and } \\
\text { ethnicity }{ }^{* *}\end{array}$ & Highest qualification & $\begin{array}{l}\text { Number of years of } \\
\text { teaching }\end{array}$ & $\begin{array}{l}\text { Number of years as an } \\
\text { associate teacher }\end{array}$ & $\begin{array}{l}\text { Preference of } \\
\text { stage of practicum } \\
\text { student }\end{array}$ \\
\hline $\begin{array}{l}\text { Athena, } \\
\text { New Zealander }\end{array}$ & $\begin{array}{l}\text { Bachelor of Education } \\
\text { (Teaching) }\end{array}$ & 27 years & Over 3 years & No preference \\
\hline $\begin{array}{l}\text { Demeter, } \\
\text { European }\end{array}$ & $\begin{array}{l}\text { Bachelor of Teaching } \\
\text { (ECE) }\end{array}$ & 27 years & Over 3 years & No preference \\
\hline $\begin{array}{l}\text { Artemis, } \\
\text { NZ European }\end{array}$ & $\begin{array}{l}\text { Diploma of Teaching } \\
\text { (ECE) }\end{array}$ & 27 years & Over 3 years & No preference \\
\hline \begin{tabular}{|l} 
Rhea, \\
European
\end{tabular} & $\begin{array}{l}\text { Diploma of Teaching } \\
\text { (ECE) }\end{array}$ & 18 years & Over 3 years & No preference \\
\hline $\begin{array}{l}\text { Hera, } \\
\text { Indian }\end{array}$ & Bachelor of Education & 20 years & Over 3 years & Stage Three \\
\hline $\begin{array}{l}\text { Leto, } \\
\text { New Zealander }\end{array}$ & $\begin{array}{l}\text { Graduate Diploma in } \\
\text { Teaching (ECE) }\end{array}$ & 5 years & $2-3$ years & No preference \\
\hline $\begin{array}{l}\text { Hestia, } \\
\text { NZ European }\end{array}$ & $\begin{array}{l}\text { Bachelor of Teaching } \\
\text { and Learning }\end{array}$ & 27 years & Over 3 years & No preference \\
\hline $\begin{array}{l}\text { Astraea, Pākehā with a } \\
\text { Māori background }\end{array}$ & Bachelor of Education & 17 years & Over 3 years & Stage One \\
\hline $\begin{array}{l}\text { Hebe, } \\
\text { New Zealander }\end{array}$ & $\begin{array}{l}\text { Graduate Diploma in } \\
\text { Teaching (ECE) }\end{array}$ & 3 years & $\begin{array}{l}\text { First time associate } \\
\text { teacher }\end{array}$ & No preference \\
\hline
\end{tabular}

*Participants were given pseudonyms to protect their identity.

** Participant ethnicities were self-reported. 
other participants also expressed that being an associate teacher was desirable in that it provided them with an opportunity to practise mentoring and gain enjoyment from it. Take, for example, Hestia, who said "I really like the whole mentoring side of working alongside teachers". This was reiterated by Astraea who thought "[It was] another step in my journey of being a mentor".

Furthermore, two associate teachers also saw becoming an associate teacher as the next step to taking on further responsibility in their careers, in that it enabled them to pass on knowledge and take on a leadership role. This leadership role was also seen as a way of providing personal professional development. Specifically, Leto stated clearly "[It was a way] to practise my leadership roles ... and provide personal professional development". The other reasons mentioned by individual participants were building reciprocal relationships, providing an extra pair of hands, and reflecting on their own and others' practice.

\section{(b) What motivates teachers to continue working as associate teachers?}

Associate teachers were motivated to continue working in this role for two main reasons. First, it allowed them to help others and support student teachers during their ITE. This is evidenced by Athena who said, "I think it is with any industry, you have done your study and people have put time in for you and I think it is only fair that you put time back into training and helping other students". Hebe also noted that "I think one of our responsibilities as teachers is to support each other and to help each other to become better teachers".

Secondly, it also provided them with a way to aid in reciprocal learning, which was clearly shown by Leto: "[I] just like the benefits I get as well, having to articulate what I do and why I do it. As well, it kind of keeps me up-to-date and keeps me accountable I guess in a way for what I do." This was further shown by Hestia who stated that "[It was] definitely to keep me motivated and current and keep me on my toes and up to date and because you learn so much from a student. I can learn from them, I'm learning from students all the time because of the conversations she comes in for, you know it is just having those deeper conversations that are brought in."

\section{(c) Does satisfaction lead to motivation?}

This study found that there were two key satisfying aspects that contributed to associate teacher motivation. Five participants said that the most satisfying aspects were giving something back to the early childhood profession and contributing to future teachers. They also acknowledged that they enjoyed seeing the growth in their students, whether it be in their confidence, in their own abilities, or in their knowledge and in their successes. Three participants also found that a satisfying aspect of the role was how the students brought another dimension, a different energy, and new ideas to their teaching, and how this in turn had an impact on the centre and the tamariki. The following were other aspects that individual participants found satisfying: the reflective moments; the positive feedback from students; helping someone with ideas; sparking students to think deeper; seeing that your contribution has been positive; smiling faces; developing relationships; networking; giving the student space to try out things; empowering; and seeing positive things in the students. For instance, Demeter stated, "The positive feedback I receive from the students and the feeling of supporting others in this job that I love, that I am passionate about". Likewise, Leto said "Just seeing the growth in the students really. How much confidence they gain in their own abilities. It's really neat to see them change."

\section{(d) Does dissatisfaction lead to demotivation?}

Participants' responses to questions about their dissatisfaction/demotivation were limited. This is because most were happy in the role, and certain negative experiences did not, overall, put them off being associate teachers. Nevertheless, the least satisfying aspect of the role was said to be paperwork (five participants). One participant also said a lack of time. The other three participants noted specific issues. These were about interruptions to the associate teacher during teaching time, student teachers removing themselves from interaction with children, overdependence on the associate teacher for reinforcement and explanation, and insufficient recognition by the visiting lecturer of the associate teacher understandings:

- "When they [students] keep coming and asking me, can I do this? Can I do that? Interrupting me on the floor is very annoying" (Hestia).

- "When they want to go into the office when the children are here and get on their iPads" (Hestia).

- "When I am feeling like they [students] are not up to task, when they just need lots of encouragement all the time and over the top explaining when you think it should have been common sense. You know, just those little frustrations that come actually with having to get back to the basics with some students and really explain everything in great detail" (Astrea).

- "I think honestly from past experience when the visiting lecturer doesn't recognise your importance because I think that undermines why we do this" (Hebe).

\section{Discussion}

\section{Initial and continued associate teacher motivation}

Sharing knowledge, encouraging student teachers, and helping the development of the profession were found to be key influences and motivating factors in the associate teacher role. Two key ideas emerged about why early childhood teachers choose to become associate teachers and are motivated to continue working in this role

The first was that associate teachers wanted to support student teachers and give something back to the profession. Several participants spoke about wanting to support students who are interested in teaching and working with young children and being a part of their journey into a career in the field of early childhood education (ECE). Whereas for others, it was more about reciprocating, giving back, contributing to future teachers, and supporting others as they had been supported through their journey to becoming a teacher. This is consistent with several other studies which found that associate teachers often feel they have skills and knowledge to offer, and see the role as an opportunity to support a new generation of teachers (Russell \& Russell, 2011; Sanders, 2005; Sinclair et al., 2006).

Similarly, a few participants in this study also expressed that in the associate teacher role they were able to reciprocally develop their observation, mentoring, and guidance skills, especially in regard to discussing assignments and giving feedback. This is akin to the findings of Minott and Willett (2011), in a small research project of four co-operating associate teachers, that associate teachers gained skills from the practicum experience; that is, using new strategies and ideas from the students, improving their role-modelling, observation, and guidance skills, giving feedback and, most importantly, self-reflection. Being able to encourage student teachers and inspire them to have the passion they themselves had for teaching and young children was also 
important to participants in the current study. Specifically, they wanted to pass on their knowledge and provide their students with a good understanding of best practice. Several other studies have also reported findings like these. For example, McDonald (2009) found that having a student was seen by associate teachers as a way of showing that they had skills and knowledge to offer student teachers.

The second key idea about associate teacher motivation was that associate teachers liked maintaining knowledge of current ECE theory and practice by working with student teachers. Associate teachers valued being kept up to date and current with ECE theory and practice through their conversations with student teachers, and in supporting them to meet their practicum assessment requirements. Several participants talked about current trends in study, teacher registration, and teacher criteria, codes, and standards. Others also added that students brought other dimensions, such as a different energy, and new ideas, which influenced their learning during the practicum experience. Beck and Kosnik (2000), Landt (2004), Simpson et al. (2007), and Villers and Mackisack (2011) all support this key point regarding professional learning and growth for the associate teachers which included reflection, a different perspective, new resources, ideas, skills, and theoretical knowledge. "The application of newer philosophical ideas, the 'latest' thinking' was also valued” (Simpson et al., 2007, p. 491). This finding also fits with the argument posed by Ferrier-Kerr (n.d.) that the quality of practicum is enhanced when associate teachers "acknowledge themselves and the student teachers as learners as well as promoting the confident practice of student teachers" (Background, para. 4).

\section{Satisfaction and dissatisfaction of associate teachers}

In addition to revealing important information about associate teacher motivation, which is largely consistent with related work in the field, this study also produced some new findings about satisfaction and dissatisfaction within the associate teacher role. Overall, it was clear that the participants enjoyed being associate teachers and found it a positive experience both for themselves and for the student teacher. Most stated that they were able to do what motivated them to become associate teachers in the first place, which was to support student teachers and keep up to date with ECE theory and practice. When asked, they also revealed that the main satisfying aspects that made them want to continue being associate teachers were seeing their students' skill and experience grow throughout the practicum process, as well as being able to explore new ideas with their students and engage in reciprocal learning. This is consistent with the findings of Ganser (2002), Hastings (2004), and Simpson et al. (2007), that most associate teachers consider working with student teachers to be a positive and rewarding experience. Beck and Kosnik (2000) also surmised that associate teachers "derived considerable satisfaction from their role" (p. 212). Moreover, the importance of personal and professional development from being in the associate teacher role, as expressed by many of the participants I interviewed, is supported by Villers and Mackisack (2011) and Russell and Russell (2011) who see the experience as a reciprocal relationship, and that working with student teachers provides benefits for all involved.

However, even though associate teachers in this study tended to find the role satisfying, they also faced some difficulties when working with students and found that the practicum experience often comes with a range of challenges, which, at times, resulted in demotivation. The main theme was that if you have a "good" student, the practicum experience is successful. But if the student needs constant reassurance, a lot of time, or makes the associate teacher question if they are in the right profession, it can be a very long practicum placement for the associate teacher. Therefore, the consensus was that, depending on the type of experience, and the type of student-teacher relationship, the motivation of associate teachers could change quite significantly. Sanders (2000, as cited in McDonald, 2009) made a similar point in her study by noting that a mindset of enthusiasm and a sense of purpose that is apparent in associate teachers can change to feelings of stress, unwillingness to have future student teachers, and a discontent with the associate teacher role.

For the participants in this study, the other key downside was the lack of sufficient time to undertake the role well. That is, they felt they often did not have enough time within their work hours to properly fulfil their requirements to their student teachers and had to spend extra time after hours with them, which sometimes caused unnecessary stress. This is also what Hastings (2004) found in a study of 28 associate teachers, where several of them expressed that, during the practicum experience, they at times felt guilt, anxiety, responsibility, disappointment, frustration, stress, and sympathy. In the current study, many of the associate teachers were also concerned about the perception that the student teacher had of them and about the visit from the education provider, in that they may have had a different interpretation of the requirements or a different view of the student. Likewise, McDonald (2009) found that some associate teachers felt the attitude of the student teacher was sometimes arrogant, and they deemed this intimidating and disrespectful. It also gave the idea that they do not care about the practicum, or care when they are not meeting their outcomes for the practicum experience. Ganser (2002) and Sim (2011) also reported that associate teachers' professional identities can be harmed by having a student teacher who is not performing or fails a practicum. This harm is because it may reflect badly on the associate teacher, and such experiences can discourage teachers from taking on the role of associate again.

\section{Conclusion}

This study confirms that the factors which motivate teachers to take up and remain in the associate teacher role are complex and multifaceted. To be specific, the findings described above indicate that the central motivation for associate teachers in ECE is to support student teachers, so that they can develop a sound understanding of theory and practice. In addition, a lesser motivation for associate teachers was that it helped them to keep current within the early childhood field. Overall, the stories that emerged from the interviews suggest that the relationships between students and associate teachers are vital in terms of what motivates the latter to take up and stay in the role. In this sense, this study has added to the field by highlighting how important it is to consider the ideas and opinions of associate teachers around what motivates them, given how crucial a role they play in the practicum experience. Specifically, it shows that only by fully considering the motivation of associate teachers, and not focusing solely on the students, can a more effective system of learning and shared knowledge be developed between associate teachers, students, and ITE providers. Going forward, I believe that the dynamics of the practicum process need to be further explored, and more of an emphasis needs to be placed on getting associate teachers to voice potential concerns and reiterate their motivation during times of stress and hardship. This could include looking at what supports associate teachers to get through practicum when things 
do become difficult and using this information to keep associate teachers motivated. For example, more comprehensive discussions with associate teachers prior to and after practicum could highlight what sort of protocols need to be put in place to avoid negative outcomes and ensure that both students and associate teachers get the most out of the experience.

\section{References}

Beck, C., \& Kosnik, C. (2000). Associate teachers in pre-service education: Clarifying and enhancing their role. Journal of Education for Teaching, 26(3), 207-224. https://doi. org/10.1080/713676888

Burr, V. (2015). Social constructionism (3rd ed.). Hove, England: Routledge. https://doi. org/10.4324/9781315715421

Education Council. (2017). Our code our standards: Code of professional responsibility and standards for the teaching profession. Wellington. Retrieved from https://teachingcouncil.nz/ sites/default/files/Our\%20Code $\% 20$ Our $\% 20$ Standards\%20web\%20booklet\%20FINAL.pdf

Ferrier-Kerr, J. (n.d.). Working together: Collaborative strategies for developing effective professional relationships in the practicum. Retrieved from http://www.aare.edu.au

Ferrier-Kerr, J. (2009). Establishing professional relationships in practicum settings. Teaching and Teacher Education, 30, 1-8. https://doi. org/10.1016/j.tate.2009.01.001

Ganser, T. (2002). How teachers compare the roles of cooperating teacher and mentor. The Educational Forum, 66(4), 380-385. https:// doi.org/10.1080/00131720208984858

Graves, S. (2010). Mentoring pre-service teachers: A case study. Australian Journal of Early Childhood, 35(4), 14-20. https://doi. org/10.1177/183693911003500403

Haigh, M., Pinder, H., \& McDonald, L. (2006, September). Practicum's contribution to students' learning to teach. Paper presented at the British Educational Research Association Annual Conference, University of Warwick, United Kingdom.

Hastings, W. (2004). Emotions and the practicum: The cooperating teachers' perspective. Teachers and Teaching: Theory and Practice, 10(2), 135-148. https://doi. org/10.1080/1354060042000187991

Jaipal, K. (2009). Re-envisioning mentorship: Pre-service teachers and associate teachers as co-learners. Teaching Education, 20(3), 257-276. https://doi.org/10.1080/10476210902887503
Kim, T., \& Danforth, S. (2012). Non-authoritative approach to supervision of student teachers: Cooperating teachers' conceptual metaphors. Journal of Teacher Education, 38(1), 67-82. https://doi.org/10.1080/02607476.2012.643 658

Landt, S. M. (2004). Professional development of middle and secondary level educators in the role of cooperating teacher. Action in Teacher Education, 26(1), 74-84. https://doi.org/10.1080/01 626620.2004 .10463315

Le Cornu, R. (2010). Changing roles, relationships and responsibilities in changing times. Asia-Pacific Journal of Teacher Education, 38(3), 195-206. https://doi.org/10.1080/13598 66X.2010.493298

McDonald, L. (2003, September). Successful associate teachers: Beliefs, attitudes and practices within a New Zealand context. Paper presented at the British Educational Research Association Annual Conference, Edinburgh, Scotland. McDonald, L. (2009). Supervision of student teachers during practicum: Beliefs, attitudes and practices of associate teachers. Saarbucken, Germany: VDM Verlag Dr Muller.

Minott, M. A., \& Willett, I. L. (2011). Studentteachers' supervision as a professional development activity: Building work-related skills. Professional Development in Education, 37(4), 537-550. https://doi.org/10.1080/19415257 .2010 .546254

Moles, J., Tanieul-Dick, B., Atiga-Anderson, V., Sauvao, L., Fuimaono, H., Ryan, S., ... \& FuliMakaua, L. (2012). (Re) Viewing the landscape and outside the box: Providing effective support for early childhood student teachers. NZRECE, 15, 145-159.

Moody, J. (2009). Key elements in a positive practicum: Insights from Australian postprimary pre-service teachers. Irish Educational Studies, 28(2), 155-175. https://doi. org/10.1080/03323310902884219

Roland, K., \& Beckford, C. (2010). Supporting associate teaching and mentoring of teacher candidates: Building a community of practice. Literacy Information and Computer Education Journal, 1(2), 103-109. https://doi.org/10.20533/ licej.2040.2589.2010.0015

Russell, M. L., \& Russell, J. A. (2011). Mentoring relationships: Cooperating teachers perspectives on mentoring student interns. The Professional Educator, 35(2), 16-35. Retrieved from http://files.eric.ed.gov/fulltext/ EJ988202.pdf

Sanders, M. (2005). Effective mentoring of student teachers: A further contribution. New Zealand Journal of Teachers' Work, 2(2), 129-135.

Sanders, M., Dowson, M., \& Sinclair, C. (2005). What do associate teachers do anyway? A comparison of theoretical conceptualizations in the literature and observed practices in the field. Teachers College Record, 107(4), 706-738.

Sim, C. (2011). "You've either got [it] of you haven't"-Conflicted supervision of preservice teachers. Asia-Pacific Journal of Teacher Education, 39(2), 139-149. https://doi.org/10.1080 /1359866X.2011.560653

Simpson, T., Hastings, W., \& Hill, B. (2007). "I knew she was watching me”: The professional benefits of mentoring. Teachers and Teaching: Theory and Practice, 13(5), 481-498. https:// doi.org/10.1080/13540600701561695

Sinclair, C., Dowson, M., \& Thistleton-Martin, J. (2006). Motivations and profiles of cooperating teachers: Who volunteers and why. Teaching and Teacher Education, 22(3), 263-279. https://doi. org/10.1016/j.tate.2005.11.008

Turnbull, M. (2005). Student teacher professional agency in the practicum. Asia-Pacific Journal of Teacher Education, 33(2), 195-208. https://doi. org/10.1080/13598660500122116

Villers, H., \& Mackisack, V. (2011). Optimizing opportunities to learn during practicum: Developing collaborative partnerships between the university and school. Asia-Pacific Journal of Cooperative Education, 12(3), 183-194.

Whatman, J., \& MacDonald, J. (2017). High quality practica and the integration of theory and practice in initial teacher education: A literature review prepared for the Education Council. Wellington: NCER.

\section{Debbie Woolston is a lecturer}

with the Whangarei Base of Te Rito Maioha Early Childhood New Zealand and has been with the organisation for 5 years. She completed her Master of Education at Waikato University in 2017, wherein she looked at the role of associate teachers in early childhood education. Her research interests tend toward better understanding and improving the practicum experience in initial teacher education, with a specific focus on the relationship between associate teachers and students.

Email: debbie.woolstonळecnz.ac.nz 